\title{
ANALISIS KARAKTERISTIK KEWIRAUSAHAAN DALAM MENGHADAPI PERSAINGAN BISNIS ONLINE DI BALE HIDROPONIK SALATIGA
}

\author{
Analysis of Entrepreneurship Characteristics Dealing With Online Business \\ Competition in Bale Hydroponic Salatiga \\ Dalmasius Apen Bangun ${ }^{1 *}$, Lasmono Tri \\ Sunaryanto ${ }^{2}$ \\ Program Studi Agribisnis, Fakultas Pertanian dan Bisnis, \\ Universitas Kristen Satya Wacana, Salatiga \\ Kontak penulis: 522016012@student.uksw.edu
}

\begin{abstract}
This research aims to 1) Analyzing the entrepreneurship characteristic by owner business. 2) Knowing the role of ownership entrepreneurship characteristic dealing with online business competition in bale Hydroponic Salatiga. Location selection is intentionally (purposive) with individual managed business considerations that apply the characteristics of the entrepreneurship. This research uses qualitative methods. The observed variable is a desire for responsibility dimension, preference for intermediate risk dimension, confidence in their ability to succes dimension, desire for immediate feedback dimension, high energy level dimension, future orientation dimension, organizing skill dimension, and value of achievement over money dimension. Then these entrepreneurial characteristics are analyzed to know the role in the face of online business competition in Bale Hidroponik Salatiga. The results of this research show the owner of Bale Hydroponik has eight variables of the entrepreneurial characteristics in running its business. The role of entrepreneurial characteristics in the face of online business competition is able to deliver products, prices, marketing, networking and services can compete.
\end{abstract}

Keywords: entrepreneurial characteristics; online business; business competition; Bale Hydroponic.

\begin{abstract}
Abstrak
Penelitian ini bertujuan untuk 1) Menganalisis karakteristik kewirausahaan yang dimiliki usaha Bale Hidroponik Salatiga 2) Mengetahui peranan kepemilikan karakteristik kewirausahaan dalam menghadapi persaingan bisnis online di Bale Hidroponik Salatiga. Pemilihan lokasi dilakukan secara sengaja (purposive) dengan pertimbangan usaha yang dikelola secara perorangan yang menerapkan karakteristik kewirausahaan tersebut. Penelitian ini menggunakan metode kualitatif. Variabel yang diamati adalah dimensi hasrat atas tanggung jawab, dimensi lebih menyukai risiko menengah, dimensi meyakini kemampuannya untuk sukses, dimensi hasrat untuk mendapatkan umpan balik yang sifatnya segera, dimensi tingkat energi yang tinggi, dimensi orientasi masa depan, dimensi keterampilan mengorganisasi, dan dimensi menilai prestasi lebih tinggi dari pada uang. Kemudian karakteristik kewirausahaan tersebut dianalisis untuk mengetahui peranannya dalam menghadapi persaingan bisnis online di Bale Hidroponik Salatiga. Hasil penelitian ini menunjukkan pemilik Bale Hidroponik memiliki kedelapan variabel karakteristik wirausaha tersebut dalam menjalankan usahanya. Peranan karakteristik kewirausahaan tersebut dalam menghadapi persaingan bisnis
\end{abstract}


online mampu membuat produk, harga, marketing, jaringan dan pelayanan Bale Hidroponik dapat bersaing.

Kata kunci: karakteristik kewirausahaan; bisnis online; persaingan bisnis; Bale Hidroponik.

Sitasi: Bangun, D. A., L. T. Sunaryanto, 2020. Analisis Karakteristik Kewirausahaan Dalam Menghadapi Persaingan Bisnis Online di Bale Hidroponik Salatiga, JSEP 16(1): $11-26$.

\section{Pendahuluan}

Indonesia merupakan negara agraris yang kaya terhadap hasil produk pertanian yang beragam, salah satunya adalah hasil produk sayuran. Sayuran merupakan kebutuhan hidup manusia yang bersifat primer. Sayuran dikonsumsi setiap hari oleh masyarakat guna untuk memenuhi kebutuhan pangan, serta memberikan dampak baik bagi kesehatan tubuh. Kondisi alam yang baik memberikan dorongan bagi sebagian besar masyarakat tertarik untuk melakukan wirausaha di sektor agribisnis pertanian.

Semakin banyaknya masyarakat yang tertarik, tentunya berdampak pada persaingan yang sangat ketat terhadap keberlangsungan usaha sayuran di pasar. Munculnya beberapa pesaing produk serupa menjadi salah satu hambatan dalam mendistribusikan produk yang siap untuk dijual ke pasar. Melihat saat ini banyaknya produk yang beragam sehingga para pelaku usaha perlu meningkatkan kinerja yang baik agar bisa berkembang dan bertahan di pasar. Untuk meningkatkan kinerja yang baik diperlukan pemahaman terhadap karakteristik kewirausahan yang dimiliki pengusaha itu sendiri.

Karakteristik kewirausahaan terdapat delapan unsur yaitu desire for responsibility artinya rasa memiliki tanggung jawab usaha-usaha yang dilakukannya. Preference for moderate risk, artinya selalu menghindari risiko, baik yang terlalu rendah maupun yang terlalu tinggi. Confidence in their ability to success, artinya memiliki kepercayaan diri untuk meraih kesuksesan. Desire for immediate feedback, artinya selalu menghendaki umpan balik dengan segera. High level of energy, artinya memiliki semangat dan kerja keras untuk mewujudkan keinginannya demi masa depan yang lebih baik. Future orientation, artinya berorientasi serta memiliki perspektif dan wawasan jauh ke depan. Skill of organizing, artinya memiliki keterampilan dalam mengorganisasikan sumber daya untuk menghasilkan nilai tambah. Serta value of achievement over money, artinya lebih menghargai prestasi daripada uang (Nugroho, 2015).

Delapan variabel karakteristik tersebut kemudian dapat menilai apakah seorang wirausaha dapat dikatakan sebagai pengusaha atau bukan. Karakteristik kewirausahan tersebut sebagai acuan bagi wirausaha dalam mempersiapkan dirinya untuk menghadapi persaingan bisnis dan meraih pasar seluas mungkin dalam menjalankan usahanya. Seperti membuat bisnis online dalam memasarkan produk pertanian untuk membantu perkembangan industri pertanian kreatif dan berkelanjutan. Berdasarkan beberapa uraian masalah diatas, maka menarik untuk dilakukan penelitian mengenai analisis karakteristik kewirausahaan dalam menghadapi persaingan bisnis online di Bale Hidroponik Salatiga.

\section{Metode Penelitian}

Penelitian ini dilaksanakan pada usaha Bale Hidroponik di Jalan Mutiara No. 35 Kelurahan Bugel, Kecamatan Sidorejo, Kota Salatiga - 50714, Jawa Tengah - Indonesia. 
Penelitian ini menggunakan metode kualitatif, dengan memahami fenomena yang terjadi melalui kalimat tertulis atau lisan, serta mengamati perilaku dari orang yang terlibat (Moleong, 2011). Teknik pengambilan sampel pada penelitian ini yaitu sampel secara sengaja (purposive sampling) yaitu peneliti membuat suatu pertimbangan tertentu berdasarkan ciri atau sifat populasi yang sudah diketahui sebelumnya. Penelitian ini tidak mengutamakan besarnya populasi, bahkan sangat terbatas (Notoatmodjo, 2005).

Adapun unit analisis dalam penelitian ini yaitu karyawan tetap dan pemilik usaha Bale Hidroponik Salatiga. Unit amatan dalam penelitian ini yaitu karakteristik kewirausahaan yang dimiliki pemilik usaha Bale Hidroponik Salatiga meliputi: desire for responsibility dimension, preference for moderate risk dimension, confidence in their ability to success dimension, desire for immediate feedback dimension, high level of energy dimension, future orientation dimension, skill of organizing dimension, dan value of achievement over money dimension. Karakteristik kewirausahaan tersebut dianalisis untuk mengetahui peranannya dalam menghadapi persaingan bisnis online di Bale Hidroponik Salatiga. Jenis data yang digunakan yaitu data primer dan data sekunder. Alat dan bahan yang digunakan yaitu kamera, telepon genggam untuk recorder, pensil, ballpoint, dan buku.

Informan kunci (key informant) adalah seseorang yang memiliki informasi pokok serta memahaminya, sehingga dapat membagikan informasi yang diperlukan dalam penelitian. Informan (informant) adalah seseorang yang terlibat langsung dalam kegiatan yang berkaitan dengan topik penelitian (Suyanto, 2003). Informan kunci (key informant) penelitian ini yaitu 2 orang pemilik usaha Bale Hidroponik Salatiga. Informan (Informant) penelitian ini yaitu 1 orang karyawan tetap usaha Bale Hidroponik Salatiga. Penentuan informan (Informant) tersebut, dimaksudkan sebagai bentuk pengujian keabsahan data dalam penelitian.

Adapun teknik analisis data menurut Miles (1992) terdiri atas empat tahapan yang harus dilakukan pada penelitian ini, yaitu:

1. Pengumpulan Data

Peneliti dalam tahap ini mengumpulankan data sebanyak-banyak yang berkaitan dengan fenomena yang diteliti melalui wawancara, observasi, FGD (Focus Group Discussion), human instrument dan dokumentasi.

2. Reduksi Data

Reduksi data merupakan proses menggabungkan dan menyeragamkan segala bentuk data (wawancara, observasi, serta hasil studi dokumentasi) menjadi suatu bentuk tulisan yang akhirnya dianalisis. Reduksi data meliputi proses meringkas data, melakukan coding, dan menelusuri tema.

3. Penyajian Data

Penyajian data merupakan proses mengolah data yang sudah diseragamkan dalam bentuk tulisan (script) dan alur tema yang jelas, berupa teks naratif.

4. Penarikan Kesimpulan

Kesimpulan merupakan tahap terakhir yang mengarah kepada jawaban dari pertanyaan yang berasal dari panduan wawancara dan mengungkapkan "apa" dan "bagaimana" dari data yang ditemukan di lapangan.

\section{Hasil dan Pembahasan}

\section{Penerapan Desire for Responsibility Dimension}

Desire for responsibility (hasrat atas tanggung jawab), yaitu memiliki rasa tanggung jawab, serta selalu bersikap hati-hati dalam menjalankan usahanya (Scarborough dan 
Zimmerer dalam Nugroho, 2015). Kedua pemilik usaha Bale Hidroponik merupakan sosok yang selalu bertanggung jawab dalam melaksanakan pekerjaan. Pemilik 1 bertanggung jawab mengatur kegiatan pemasaran yang dijalankan, sedangkan pemilik 2 bertugas di bagian produksi yang berkaitan dengan kebutuhan produk.

"Kalau saya lebih banyak ke pemasarannya, tanggung jawabku memastikan ordernya jalan dan produk terjual atau pelempar ke konsumen. Terus memastikan kuota orderan sehari berapa, lalu aku ingatin Tito untuk menjamin produk yang aku minta ada."

Pemilik Bale Hidroponik mempunyai tanggung jawab memberikan perlakuan yang baik terhadap pelanggannya. Pemilik selalu mengontrol penuh atas kegiatan yang dijalankan, sehingga pemilik dapat berinteraksi langsung dengan karyawannya. Hal ini sejalan dengan penelitian Ramdani (2016), bahwa selalu berhati-hati dalam menjalankan usaha menjadi elemen terpenting untuk konsistensi bisnis di bidang pertanian modern yang dijalankannya.

"Setahun pertama iya saya mengontrol, tahun kedua mulai dibagi tugas, terus tahun ketiga mulai mencoba untuk enggak handle beberapa. Kami itu pengen bisnis kami bertiga, pengennya bisnis kami sistemnya autopilot, yang ngerjain itu orang lain....."

Pernyataan tersebut diperkuat oleh karyawan Bale Hidroponik:

"Sejauh ini mereka sudah memperlakukan konsumen dengan baik, kayak misalnya konsumen protes kok ini kecil, nah itu jadi evaluasi bagi kita, itu PR banget...."

Berdasarkan teori Scarborough dan Zimmerer dalam penelitian Nugroho (2015), pemilik usaha Bale Hidroponik memiliki karakteristik kewirausahaan desire for responsibility dimension (hasrat atas tanggung jawab), dikarenakan pemilik Bale Hidroponik telah menjalankan indikator-indikator yang diinginkan yaitu rasa memiliki tanggung jawab penuh atas bisnis yang dijalankan, ikut turut serta dalam mengontrol seluruh proses bisnisnya dan perlakuannya harus baik ke semua pelanggan.

\section{Penerapan Preference for Moderate Risk Dimension}

Preference for moderate risk (lebih menyukai risiko menengah), artinya mempertimbangkan secara matang terlebih dahulu sebelum memutuskan sesuatu (Scarborough dan Zimmerer dalam Nugroho, 2015). Pemilik Bale Hidroponik selalu mempertimbangkan dengan matang dalam memutuskan sesuatu. Dalam menentukan keputusan tersebut pemilik secara terbuka dengan melibatkan karyawan. Pemilik melakukan mind mapping dalam melakukan pekerjaan sehingga pekerjaan dapat tersusun secara beraturan.

"Selalu mempertimbangkan keputusan iya, yang sudah berjalan selama ini berkaitan dengan visi dan misi harus dipertimbangkan kedepannya. Kami itu termasuk yang suka bikin mind mapping kalau mau merencanakan kegiatan, misalnya perlengkapan store yang mau digunakan, dan keuangan juga. Terus rapat dulu sebelumnya buat membicarakan pemetaan konsep kegiatan kedepannya, sudah beberapa kali."

Pemilik Bale Hidroponik berusaha mengambil risiko yang sangat wajar, dengan memperhatikan ketersediaan produk, serta mempertimbangkan waktu dalam menyelesaikan produk yang dikerjakan dengan memberikan open order. Jika 
pengambilan risiko yang wajar tidak dapat dikerjakan, dengan menghindari risiko, seperti kehilangan omset usaha. Solusi pemilik dengan membuka toko online delivery sayur khusus di daerah Salatiga. Selain itu produktivitas sayuran yang di budidayakan tergantung pada pengaruh cuaca yang tidak menentu, solusinya dengan memanfaatkan produk dari mitra produksi. Jika pemilik Bale Hidroponik merasa pelayanan yang diberikan kurang yakin, maka diberikan pelayanan tambahan.

"Iya. Contohnya yang pertama kalau ada yang pesan produknya kami tidak ada, sebisa mungkin kami carikan, kami tanyakan ke mitra kami dulu apakah ada produknya....."

"Kalau dari segi waktu, misalnya pesan dadakan dan waktunya terbatas kalau memungkinkan kami coba ambil dan kalau misalnya nggak memungkinkan kami yang relatif tidak ambil....."

"Kalau misalnya situasi kayak gini Semarang lagi lockdown karena covid-19. Misalnya ada 100\% omset yaitu dari Semarang ada 2 store, Salatiga ada 3 store dan resto ada 5 berarti 10 tempat itu sumber omsetnya harus terbagi rata berarti semuanya harus dibagi masing-masing 10\%. Kalau misalnya kita kasi 50\% sendiri ke Semarang, takutnya dia tutup berarti kita kehilangan 50\% omset, nah itu yang kami takutkan sekarang, makanya kami juga bantu dengan cepet-cepet bikin store, supaya kasnya tetap jalan....."

Berdasarkan teori Scarborough dan Zimmerer dalam penelitian Nugroho (2015), mengenai variabel preference for moderate risk dimension (lebih menyukai risiko menengah) pemilik usaha Bale Hidroponik memiliki karakteristik kewirausahaan tersebut. Pemilik mampu mempertimbangan matang sebelum memutuskan sesuatu, mampu mengambil risiko yang wajar, berusaha menghindari risiko, serta bila kurang yakin atas pelayanan yang diberikan, memberikan layanan tambahan.

\section{Penerapan Confidence in Their Ability to Success Dimension}

Confidence in their ability to success (meyakini kemampuannya untuk sukses), yaitu seorang pengusaha memiliki kepercayaan diri, sikap optimis, serta menganggap adanya tantangan sebagai rangsangan untuk menjadi lebih baik lagi (Scarborough dan Zimmerer dalam Nugroho, 2015). Pemilik sangat percaya diri dalam menjalankan usahanya ketika melihat banyaknya masyarakat mengenal Bale Hidroponik di media sosial. Model usaha yang ingin diterapkan pemilik saat ini yaitu model franchising. Pemilik yakin jika membuka cabang di berbagai daerah dapat memperluas pasar.

"Iya. Kalau yakin dan percaya diri sih lumayan yakin, melihat perkembangan yang baik juga saat ini. Perkembangan setelah masuk Net TV, aku lihat kemarin sampai 7000 orang yang akses Balai Hidroponik kan lumayan....."

Pemilik Bale Hidroponik selalu optimis untuk keberlangsungan usahanya. Pemilik menganggap bahwa suatu tantangan menjadi motivasi dan pelajaran agar usaha ini dapat berkembang lebih baik lagi. Pemilik berusaha untuk tidak panik dan selalu mencari jalan keluar dalam menghadapi tantangan yang ada. Sikap pemilik yang dapat mengambil hikmah dan sisi positif, dapat mempengaruhi orang disekitarnya. 
"Responsif aja, kami biasanya kalau ada masalah gitu, misalnya anak PKL mulai bergerak harus keluar karena covid-19 dan dipulangkan. Solusinya kalau misalnya mau lockdown harus cepat-cepat isi stoknya, dan jangan panik intinya tenang."

Pernyataan tersebut diperkuat oleh karyawan Bale Hidroponik:

“.... Aku ngeliat mereka kayak orang yang bisa mengambil di sisi positifnya dari hal itu, jadi kayak baik-baik aja, nah sikap itu juga yang bikin kami nyaman, berarti dalam artian pahit manisnya pekerjaan itu jadi enak, sekalipun ada cobaan masalah atau apapun habis itu ya udah kayak profesional gitu, jadi fine-fine aja."

Berdasarkan teori Scarborough dan Zimmerer dalam penelitian Nugroho (2015), mengenai variabel confidence in their ability to success dimension (meyakini kemampuannya untuk sukses) pemilik usaha Bale Hidroponik memiliki karakteristik kewirausahaan tersebut, seperti memiliki kepercayaan diri yang kuat, optimis, serta menganggap tantangan sebagai rangsangan untuk lebih baik lagi dan mampu mengambil sikap dalam menghadapi segala hambatan yang terjadi.

\section{Penerapan Desire for Immediate Feedback Dimension}

Desire for immediate feedback artinya selalu menghendaki umpan balik dengan segera (Scarborough dan Zimmerer dalam Nugroho, 2015). Pemilik Bale Hidroponik selalu terbuka dan menerima kritik dan saran yang diberikan. Ketika ada kritik saran yang diberikan menjadi semangat bagi pemilik untuk membuktikan yang di katakan orang lain tidak selalu benar. Saat ini kritik dan saran yang paling banyak diterima oleh pemilik yaitu dari beberapa mitra penjualan seperti resto dan supermarket. Pemilik mengusahakan keinginan pelanggan dengan fokus perbaikan kualitas sayuran yang diberikan.

"Dulu itu Bale ada karena kritik dan saran, atasan aku bilang bisnisnya tidak menjanjikan. Makanya dulu jengkel banget, kok gitu sih sampai sekarang sebenarnya masih dendam tapi akhirnya membuahkan hasil...."

"Kayak konsumen komplain soal gramasi, ukuran kita perbaikin."

Pernyataan tersebut diperkuat oleh karyawan Bale Hidroponik:

"Kalau bisa dibilang sejauh ini untuk ke end user, mereka ngasi kritik dan saran malah hampir gak ada sih, kalau responnya sih baik mereka selalu menerima....."

Berdasarkan teori Scarborough dan Zimmerer dalam penelitian Nugroho (2015), mengenai variabel desire for immediate feedback dimension (hasrat untuk mendapatkan umpan balik yang sifatnya segera) pemilik usaha Bale Hidroponik memiliki karakteristik kewirausahaan tersebut. Pemilik selalu terbuka terhadap saran dan kritik, kemauan untuk membuat pelanggan puas. Sikap menerima tersebut membuat pelanggan nyaman atas layanan yang diberikan sehingga usaha ini dapat berkembang dan bersaing. 


\section{Penerapan High Level of Energy Dimension}

High level of energy (tingkat energi yang tinggi), yaitu memiliki semangat dan kerja keras untuk mewujudkan keinginannya demi masa depan yang lebih baik (Scarborough dan Zimmerer dalam Nugroho, 2015). Pemilik Bale Hidroponik selalu memiliki rasa semangat yang tinggi, sehingga dapat meningkatkan motivasi dalam bekerja. Semangat pemilik menjadi contoh bagi karyawan yang bekerja, sehingga suasana lingkungan kerja menjadi nyaman.

"Ingat keluarga sih, dan ingat mimpi yang pengen diraih dari Bale Hidroponik itu aja."

Pernyataan tersebut diperkuat oleh karyawan Bale Hidroponik:

"Kalau selama 8 bulan ini berjalan, yang bikin nyaman kerja di sini itu lingkungannya mereka berdua, mereka menciptakan suasana enak...."

Pemilik Bale Hidroponik menekankan tekad kerja keras dalam mewujudkan keinginannya. Namun pada usahanya pemilik lebih menekankan bekerja cerdas. Pekerjaan yang dijalankan dianggap sebagai pekerjaan utama yang patut diperjuangkan. Pemilik juga meyakini sikap tidak mudah menyerah juga mampu membuat pemilik bertahan dalam mejalankan usahanya, dengan mempertimbangkan waktu, tenaga dan modal yang sudah dikeluarkan cukup banyak. Sikap disiplin juga selalu ditekankan untuk memenuhi deadline dan tuntutan keuangan perusahaan. Sikap disiplin diterapkan pemilik kepada karyawan ketika ada hal-hal yang terlupakan.

"Iya, cuma ada namanya kerja keras sama kerja cerdas, dan kerja cerdas ini menurutku yang paling terpengaruh, kami percaya sama mind mapping di awal itu pengaruh banget, deadline mau ngapain di lihatin satu-satu nanti sampai ke tujuan nya....."

Pernyataan tersebut diperkuat oleh karyawan Bale Hidroponik:

".....mereka selalu disiplin ingatin aku, kayak setiap hari Rabu ngirim tagihan yang harus dibayar, kadang aku kelewat siang baru ngirim, jadi paginya ingetin dikirim ya."

Berdasarkan teori Scarborough dan Zimmerer dalam penelitian Nugroho (2015), mengenai variabel high level of energy dimension (tingkat energi yang tinggi) pemilik usaha Bale Hidroponik memiliki karakteristik kewirausahaan tersebut, seperti selalu bersemangat dalam menjalankan pekerjaan, tekad kerja keras, sikap tidak mudah menyerah, dan disiplin dalam menjalankan pekerjaan.

\section{Penerapan Future Orientation Dimension}

Future orientation (orientasi masa depan), yaitu wirausaha selalu berorientasi, memiliki pandangan dan wawasan yang jauh ke masa depan usaha (Scarborough dan Zimmerer dalam Nugroho, 2015). Pemilik Bale Hidroponik mampu melihat peluang di masa depan untuk mencapai target yang diinginkan. Pemilik menganggap bahwa pekerjaan yang dipikirkan dalam jangka panjang beguna untuk keberlangsungan usaha, seperti perencanaan kegiatan pemasaran dan operasional. Pemilik merintis toko online guna untuk mendukung kegiatan pemasaran dan keberlangsungan persaingan 
usaha. Sistem delivery yang baru dijalankan melalui toko online mungkin saja dapat meningkatkan omset usaha dan membuat skala usahanya semakin lebih besar.

"Iya. Terus udah kita ada mind mappingnya gitu, jadi ibaratnya target Bale tahun depan mau ngapain sudah bisa cerita ke orang yang banyak, kayak pengen masuk acaraacara TV kalau bisa. Kita juga harus ada visi dan misi nya kedepan harus ngapain aja."

Pernyataan tersebut diperkuat oleh karyawan Bale Hidroponik:

“....pemikiran kita udah jalan 3 tahun terus pengen punya satu tempat yang memang kayak toko kita gitulah, mikirnya ke depan banyak project-project yang kayak kitanya mau delivery, kayak gitu-gitu orientasinya ke depan, entah itu sisi skala usahanya makin besar, omsetnya makin besar pasti mikir ke depan."

Pemilik Bale Hidroponik mempunyai visi dan misi perusahaan yang ingin dicapai. Pemilik ingin usahanya dapat berkembang ke arah yang lebih luas. Selain itu disisi lain pemilik ingin kebutuhan finansialnya dapat terpenuhi dan dapat membantu banyak orang di sekitar usahanya.

"Autopilot sih pengennya, jadi dulu awal kami sepakat Bale itu bisa jalan sendiri, untuk ngelepasnya sistemnya harus teratur."

"Kalau dari visi dan misi aku sendiri aku bisa pengennya kebutuhan finansial ku terpenuhi, aku juga pengen bantu orang banyak yang butuh juga...."

Sikap pemilik Bale Hidroponik tidak mudah puas dengan pencapaiannya menjadi dorongan untuk lebih baik. Ketika pemilik tidak puas atas hasil pekerjaan yang didapatkan, dilakukan perbaikan manajemen pekerjaan. Pemilik juga selalu berkaca atas pekerjaan yang sudah dijalankan, sehingga masih dapat dikembangkan dan diperbaiki secara pribadi. Dalam memperbaiki manajemen pekerjaan tentunya pemilik juga mempertimbangkan masukan yang diberikan oleh karyawan yang bekerja.

"Iya. Kalau bahasanya kami tambal sulam sih, kalau kemarin misalnya kami ada kurangnya terus manajemen ditambah dalam konteks pribadi-pribadi....."

Pernyataan tersebut diperkuat oleh karyawan Bale Hidroponik:

"Iya. Jadi ini misalnya masukan dari aku kok sistem pembukuan ini tuh ribet-ribet nya di sini, ya udah kita omongin dulu....."

Berdasarkan teori Scarborough dan Zimmerer dalam penelitian Nugroho (2015), mengenai variabel future orientation dimension (orientasi masa depan) pemilik usaha Bale Hidroponik memiliki karakteristik kewirausahaan tersebut, seperti berorientasi jauh kedepan, terdapat visi dan misi usaha maupun pribadi, sikap tidak mudah puas dengan pencapaiannya, serta selalu melakukan perbaikan manajemen pekerjaan.

\section{Penerapan Skill of Organizing Dimension}

Skill of organizing (keterampilan mengorganisasi), yaitu keterampilan untuk mengorganisasikan, mengarahkan sumber daya yang ada guna memperoleh nilai 
tambah (Scarborough dan Zimmerer dalam Nugroho, 2015). Pemilik Bale Hidroponik berusaha untuk memberikan motivasi kepada karyawan yang bekerja. Pemilik selalu berusaha meyakinkan dan memberikan arahan yang baik ketika karyawan melakukan pekerjaannya sesuai yang diinginkan pemilik, terutama pekerjaan yang berisiko tinggi, sehingga karyawan merasa nyaman dan semangat ketika diperhatikan.

"Kalau aku untuk memotivasi diri aku sendiri itu lebih sulit, tapi memotivasi orang lain gampang. Aku merasa puas ketika di level tertinggi dari sebuah keikutsertaan dalam suatu usaha, yaitu yang lain tuh bisa ngasih usul....."

"Iya ada, jadi kalau contohnya kayak kerja yang resikonya tinggi itu misalnya setiap hari Selasa anak PKL ke Semarang untuk antar sayur, aku selalu nggak bosen-bosen ngomong kalau jalan nggak usah kencang-kencang yang penting selamat, kalian tahu pembagian waktunya segini-segini di tempat yang ini, yaudah itu dioptimalkan aja nggak usah buru-buru sampai harus gaspol motornya biar cepat sampai, yang penting kalian aman, deliverynya aman dan bisa sampai Salatiga dengan aman."

Pemilik Bale Hidroponik mampu memberikan tugas kepada pegawai sesuai keterampilan. Pemilik juga mampu melakukan pengarahan yang baik kepada karyawan, terutama yang belum berpengalaman. Tugas yang ditentukan pemilik diberikan sesuai kebutuhan masing-masing, seperti operasional, administrasi, dan pemasaran. Pemilik memberikan kepercayaan kepada karyawan lama untuk membantu mengarahkan karyawan yang baru.

"Kami kasih tugasnya sesuai kebutuhan aja sih ke masing-masing. Kami bertiga toh, urutannya di operasional kami ada mas Tito, nah dibantu teman-teman PKL dan juga teman-teman part time. Terus di administrasi karena makin gede laporan keuangannya dan nggak jalan juga terus dikasih orang itu ada Maria, terus aku di pemasarannya....."

Pemilik Bale Hidroponik masih belum mampu mengelola sumber daya yang inovatif, dikarenakan sulitnya melakukan diferensiasi produk sayuran yang ada. Pemilik juga berusaha membuat usahanya lebih kreatif dengan memanfaatkan media sosial seperti instagram, facebook, youtube, dan whatsapp dalam pemasaran. Pemilik selalu mudah dalam menggunakan teknologi yang baru dalam pekerjaan, seperti alat otomatisasi hidroponik yang dapat memudahkan dalam pekerjaan. Pemilik menganggap alat ini dapat mengatasi masalah SDM yang terbatas, serta alat ini dapat melakukan pengecekan melalui database yang tersimpan. Pemilik ingin kedepannya memanfaatkan teknologi yang tepat untuk memudahkan konsumen dalam pembelian, serta mampu mendukung kegiatan pemasaran.

"Kita menyadari kalau buat produk kita beda tuh enggak gimana-gimana, susah banget, akhirnya kita di promosinya jadi biar orang-orang notice oh ada tempat sayur di Bale Hidroponik, kalau promosinya tuh kayak di instagramnya Bale itu aneh-aneh isinya kayak video kak Tito di green house trending, biar orang bisa notice ada Bale hidroponik dan kebetulan karena sasaran pasarnya menengah ke atas dan usia-usia muda....."

"Fleksibel penggunaan teknologi yang modern dalam pekerjaan pengen sih iya, Jadi ada inovasi otomatisasi untuk hidroponik, bisa ngatasi masalah SDM, kalau lewat SDM tiap hari ngasih nutrisi pasti mereka tidak melakukan jobdescnya dengan baik, kadang 
pagi cek sorenya nggak, atau pagi pas cek males jadi asal-asalan, nah ini tuh nggak, pakai database udah bagus....."

Dalam mengelola keuangan pemilik Bale Hidroponik mampu menyediakan modal dalam usaha, serta mampu bekerjasama dengan investor untuk memenuhi kebutuhan finansial usahanya. Pemilik selalu membuat perencanaan keuangan agar dapat membuat pengeluarannya lebih sedikit, dengan dibantu karyawan yang berpengalaman di bidang administrasi. Pemilik juga mampu mengelola pemasaran yang baik, dengan memasarkan produk yang dibutuhkan kosumennya. Namun pemilik ingin mengetahui lebih lanjut mengenai pangsa pasar yang di inginkannya. Pemilik mempertimbangkan harga dalam menentukan target pasar, sehingga tidak memaksakan konsumen untuk membeli. Konsumen utama yaitu masyarakat menengah keatas yang mengerti khasiat sayuran sehat hasil metode hidroponik.

"Hampir 18 jutaan sih kalau ditotal dari 10 mitra itu sebulan, Gelael paling banyak cash flownya 5 jutaan sebulan, ada 2 berarti 10 juta, sisanya di Salatiga, rata-rata satu jutaan sih."

"Untuk target pasarnya kami nentuin dari harga, kalau harganya tinggi nggak bisa memaksakan orang yang berpenghasilan menengah kebawah untuk beli, walaupun mereka punya awareness yang tinggi, value nya ini bagus mereka mau beli, tapi diluar target jadi yang target itu emang orang yang menengah ke atas. Tapi yang belum kami lakukan sebelum yaitu survei kebutuhan mereka, siapa tahu pendekatannya kami salah ketika kami nyasar mereka juga nggak antusias banget, tapi peta konsumennya setelah kami buka untuk end user mulai ketebak, ternyata kayak di instagram target marketnya menengah ke atas kayak ibu-ibu muda seumuran punya anak satu itu banyak, jadi kebantu."

Berdasarkan teori Scarborough dan Zimmerer dalam penelitian Nugroho (2015), mengenai variabel skill of organizing dimension (keterampilan mengorganisasi), pemilik usaha Bale Hidroponik memiliki karakteristik kewirausahaan tersebut seperti berjiwa kepemimpinan dalam memotivasi, mudah beradaptasi dengan orang lain, mampu membagi tugas kepada pegawai sesuai keterampilan, mampu mengarahkan pegawai, mampu mengelola sumber daya inovatif, kreatif dan fleksibel, serta kemampuan mengelola keuangan dan pemasaran.

\section{Penerapan Value of Achievment over Money Dimension}

Value of achievement over money yaitu pengusaha cenderung untuk lebih mengutamakan pencapaian dibanding uang yang didapatkan (Scarborough dan Zimmerer dalam Nugroho, 2015). Pencapaian adalah hal yang paling diinginkan oleh pemilik Bale Hidroponik untuk saat ini. Uang bukan menjadi hal yang utama, tetapi manfaat value yang diperoleh yang diutamakan. Hal yang menjadi kepuasan bagi pemilik Bale Hidroponik yaitu ketika konsumen puas atas produk dan pelayanan yang diberikan. Kepuasan yang diberikan pemilik kepada pelanggan yaitu dengan mementingkan jaminan kualitas produk yang diberikan. Hal yang paling berpengaruh ketika konsumen membeli dan memposting sayuran melalui media sosial, sehingga dapat menyebarluaskan usaha. 
"Proses pencapaian usaha sih, nah kami pengen manfaat value ada, cuman kayak kegiatan edukasi itu nggak terlalu dapat banyak uang, tapi lebih ke arah mitranya banyak. Untuk tujuannya sampai kesana support-nya harus banyak."

Pernyataan tersebut diperkuat oleh karyawan Bale Hidroponik:

".....nah dia promo di instagramnya tanpa kita minta, itu adalah apresiasi menunjukkan kepuasan mereka."

Berdasarkan teori Scarborough dan Zimmerer dalam penelitian Nugroho (2015), mengenai variabel dimensi value of achievement over money dimension (menilai prestasi lebih tinggi dari pada uang), pemilik usaha Bale Hidroponik memiliki karakteristik kewirausahaan tersebut yaitu kecendrungan lebih menghargai proses dari pada uang. Konsumen yang puas atas pelayanan yang diberikan membantu menyebarluaskan informasi mengenai usaha ke masyarakat, sehingga usaha ini dapat bersaing di pasar.

\section{Bisnis Online}

Bisnis online merupakan kegiatan pemasaran yang dilakukan melalui dunia maya atau dunia virtual, dimana suatu bisnis online dapat membangun sebuah bisnis nyata dengan mudah (Sulianta, 2012). Bisnis online ini dilakukan pemilik Bale Hidroponik dalam memberikan informasi bahwa adanya usaha ini di lingkungan masyarakat. Pemilik berkomunikasi dengan konsumen melalui media sosial instagram dan whatsapp yang di layani oleh karyawan di bagian admin.

Pemilik Bale Hidroponik merasa manfaat yang diperoleh ketika memasarkan produknya melalui media sosial dapat meningkatkan penjualan. Apalagi saat ini penjualan sangat meningkat ketika adanya wabah covid-19 dikalangan masyarakat, dikarenakan adanya peningkatan kebutuhan bahan makanan. Menurut Tritama et al. (2014), kegiatan pemasaran melalui media sosial juga dapat menarik konsumen untuk membeli, sehingga berdampak pada brand awareness perusahaan. Menurut pemilik Bale Hidroponik jika dikelola secara benar dapat secara efektif meningkatkan brand awareness. Melalui postingan menarik, akhirnya usaha ini dapat dikenal banyak orang.

"Sekarang bisa banget, jadi respon soal covid-19 terus pada alihin ke delivery, kami kaget juga biasanya ambil dikit sekarang ambil banyak....."

"Iya. Kadang teman SMP aku dulu kalau ketemu ngomongnya aku juragan sayur....."

Bisnis online yang dijalankan pemilik Bale Hidroponik dapat memperkenalkan produk yang dijual. Namun mengingat sangat banyaknya jenis sayur di toko, pemilik berusaha memperkenalkan melalui postingan dan konten video di instagram. Menurut Widyaningrum (2016) bahwa mempromosikan bisnis menggunakan media sosial dapat menjaring pelanggan baru. Hal ini terbukti pada usaha Bale Hidroponik dilihat dari konsumen yang mengakses media sosial sangat banyak. Wajar saja ada pelanggan baru yang tidak dikenal datang untuk membeli produk.

"Iya bener beberapa iya. Cuma produknya kan ada 40 jenis sayur, masih PR kira-kira gimana mengemasnya supaya orang tahu kami punya banyak jenis sayur." 
"Akhirnya iya, jadi ceritanya itu awal-awal itu aku nggak follow yang dari aku kenal, ada 500 orang, nah selebihnya dia itu jalan sendiri gitu, jadi mulai orang randomrandom dari mana-mana, itu banyak banget."

Pemilik Bale Hidroponik selalu menjaga komunikasi yang baik dengan resto dan supermarket melalui media sosial. Bale Hidroponik rutin melakukan tag ke media sosial mitra, itulah salah satu bentuk komunikasi yang menguntungkan bagi kedua pihak. Pemilik juga merasa melalui media sosial mampu menghemat biaya promosi yang dikeluarkan, serta dapat melakukan penawaran secara langsung ke konsumen. Hal ini selaras dengan pendapat Romdonny et al. (2018), bahwa peranan media sosial memiliki dampak untuk mengurangi biaya promosi.

“.....kita mulai rutin ngirim ke supermarket Gelael, kita ngetag ig-nya terus mereka respon oh Bale yang nyetok sayur ya, mungkin simpel tapi aku ngerasa itu salah satu bentuk berkomunikasi dengan mereka....."

"Kami biaya promosi 0 rupiah, belum ada Instagram ads, Facebook ads dan Google ads. Pertama sih Instagram dulu karena kuat kami di situ."

Menurut Bambang dan Ayu (2015) media sosial memungkinkan pengguna untuk mengirim atau mempublikasikan konten menjangkau secara luas dan mendapatkan umpan balik. Menurut pemilik Bale Hidroponik media sosial juga mampu menjangkau secara global dalam pemasaran produk. Pemilik seringkali mendapat respon dari konsumen luar daerah usahanya. Pemilik juga merasa jika dibandingkan dulu sebelum menggunakan media sosial tidak sebanyak pada saat ini, artinya target pelanggan yang diinginkan saat ini tercapai. Hal ini sejalan dengan Juditha (2017), yang menyimpulkan melalui media sosial dapat meningkatkan pelanggan, saat pelanggan mengunjungi situs produk tertentu mereka kemudian tertarik untuk membelinya.

"Iya. Kemarin banyak banget yang nanya dari Lampung, Medan, Kalimantan. Kayak dari Bogor ada telepon tanya tentang nutrisi cocoknya gimana, nah kayak gitu kami layanin untuk jaringan, terus sampai sekarang hampir kayak keluarga. Mereka juga pernah ke sini sampai minta pakcoy, pagoda. Jadi lumayan bisa ngenalin produk kami."

"Menambah iya, menambahnya mungkin ke jumlahnya, jadi lebih kaya kalau dulu dulu orang-orang sekitar rumah, nah sekarang orang-orang yang kita nggak kenal sama sekali. Terus variasi dulu lewat media sosia banyak anak muda, sekarang merambat ke ibu-ibu rumah tangga yang tau media sosial juga udah ada."

Pemilik Bale Hidroponik memanfaatkan media sosial yang cocok dengan target pasarnya, serta mampu mendukung strategi pemasaran. Pemilik meyakini dengan adanya manfaat jika melakukan pemasaran melalui media sosial dapat meningkatkan persaingan usaha. Buktinya ketika Fiskom UKSW mencari atau survei mengenai iklan yang dicari, Bale Hidroponik menjadi usaha yang muncul paling teratas, artinya dari segi positioning-nya cukup tinggi, hal tersebut dipengaruhi karena rutin upload di youtube, dan instagram.

"Mendukung banget, sudah pas dalam artian media sosial yang dipilih sejauh ini IG, dan memang sasaran pasarnya adalah orang-orang muda, jadi nyambung. Kemudian 
ketambahan sama konten-konten yang ada di dalamnya yaitu kita buat unik yg banyak komedinya itu lebih nyambung ke sasarannya....."

"Jadi kemarin itu tahunya malah dari anak Fiskom, jadi mereka mau bikin iklan, nah mereka itu kalau bikin iklan survei dulu, Bale itu positioningnya itu seberapa di Salatiga, mereka tuh cari Bale Hidroponik ternyata muncul paling atas berarti kalau di lokal udah lumayan bersaing....."

Dapat ditarik kesimpulan bahwa media sosial Bale Hidroponik mampu memberikan dampak postif terhadap persaingan bisnis antara usaha sejenis. Hal ini sesuai dengan yang dikatakan Situmorang et al. (2018), bahwa keuntungan dan peranan yang didapat ketika mengelola pemasaran melalui bisnis online bagi pengusaha yaitu meningkatkan penjualan, meningkatkan brand awareness, memperkenalkan produk yang dijual, menarik pelanggan baru, meningkatkan loyalitas, menghemat biaya promosi, membantu jangkauan global, menambah target pelanggan, dan mendukung strategi pemasaran guna menghadapi persaingan bisnis.

\section{Persaingan Bisnis}

Menurut Lubis et al. (2017), persaingan bisnis merupakan suatu proses di mana para pelaku bisnis dua atau lebih yang dituntut menjadi wirausaha yang efisien dalam menawarkan produk dan jasa di pasar. Dalam menghadapi persaingan bisnis pemilik Bale Hidroponik berharap bahwa kompetitor yang ada dipasar dapat dijadikan mitra. Dari segi produk supaya mampu bersaing pemilik berusaha melakukan modifikasi yang unik, serta mengikuti kualitas sesuai standard pasar. Pemilik menentukan harga dengan menyesuakan harga yang ada di pasar, serta memberikan pelayanan edukasi untuk menambah nilai tukar kepada konsumen, sehingga dari segi harga mampu bersaing dipasar. Pemilik juga berusaha untuk tidak menaikan harga di konsumen.

"Dari segi produk kita bagusin lewat packing-nya jadi fisiknya memang harus bagus dan harus memuaskan pelanggan gitu, kedua packing-nya harus bersih harus rapi terus harus jelas aja jadi kami kasih jenis sayurnya jadi orang tahu ini pakcoy."

"Kalau harga produk hidroponik sebenarnya marginnya kita itu tinggi lumayan tinggi. Jadi BEP yang di pasaran itu tinggi banget, nah kami nyesuain yang di pasar, target kami resto dan swalayan, terus produk kami ada edukasinya."

Menurut Syukron (2016), dalam pemasaran pengusaha dituntut mulai menyadari bahwa marketing sangat penting selain untuk keunggulan bersaing, survive dan pertahanan perusahaan dari incaran pihak ketiga, serta harus cerdas dan trampil dalam melakukan action. Pemilik usaha Bale Hidroponik berusaha menarik pelanggan dengan memberikan diskon di media sosial instagram. Pemilik menjalin kerjasama dengan memanfaatkan kegiatan seminar ke berbagai kampus untuk melakukan promosi. Kerjasama yang dijalankan oleh pemilik Bale Hidroponik melalui media sosial mampu meningkatkan jaringan kerja di wilayah Salatiga dan Semarang yang ada sehingga dapat bersaing. Pemilik berusaha menambah mitra sebanyak mungkin agar dapat menampung permintaan pasar. 
"Kita sudah pikiran marketingnya untuk teman-teman yang di swalayan terutama, kita kasih misalnya diskon beli 2 gratis 1. Terus diskon 17\% di tanggal 17 agustus....."

"Kalau mitra penjualan total ada 10 mitra yang terdiri dari 5 Supermarket dan 5 restoran yang ada di Semarang dan Salatiga....."

Peningkatan kepuasan pelanggan mencerminkan pelayanan yang baik untuk superioritas suatu pelayanan yang berdampak terhadap keunggulan bersaing (Herman, 2018). Pemilik merasa pelayanan yang diberikan sejauh ini sudah cukup bersaing. Cara pemilik memberikan pelayanan dengan memberikan service pelayanan terhadap produk dengan melebihkan berat pada setiap produk kepada pelanggan.

"Biasanya kalau ke resto mereka pesan 2 kilo, kami jarang banget ngasih 2 kilo pas biasanya kami ngasih lebihin 100-200 gram, tapi mereka bayar tetap 2 kilo....."

Berdasarkan teori Didin \& Hendri (2002), kesimpulannya dalam menghadapi persaingan usaha pemilik usaha Bale Hidroponik sudah memilik kekuatan-kekuatan dalam bersaing sebagaimana yang telah disebutkan yaitu pada produk, harga, marketing, jaringan, dan pelayanan. Melalui karakteristik kewirausaan yang dimiliki oleh pemilik usaha Bale Hidroponik, pemilik merasa yakin berperan penting terhadap produk, harga, marketing, jaringan kerja, serta pelanyanan yang dijalankan sejauh ini sudah mampu bersaing di pasar. Perlunya perbaikan manajemen pekerjaan secara terus menerus untuk tetap bersaing di pasar.

\section{Kesimpulan}

1. Penerapan desire for responsibility, yaitu: pemilik usaha Bale Hidroponik menjalankan bisnisnya dengan penuh tanggung jawab. Pemilik memberikan perlakuan baik kepada pelanggan dan turut mengontrol seluruh proses bisnis.

2. Penerapan preference for moderate risk yaitu: pemilik usaha Bale Hidroponik selalu menanamkan di dalam dirinya sendiri bahwa segala bentuk resiko harus dihadapi, salah satunya dengan mind mapping untuk memanajemen resiko.

3. Penerapan confidence in their ability to success, yaitu: sebagai leader sikap percaya diri, optimis, serta mampu menghadapi segala kondisi dengan sikap yang baik.

4. Penerapan desire for immediate feedback yaitu: pemilik usaha Bale Hidroponik sangat terbuka dengan masukan dari para pelanggannya. Untuk internal perusahaan, karyawan bisa sharing dalam pertemuan yang dilakukan saat bekerja.

5. Penerapan high level of energy yaitu: pemilik usaha Bale Hidroponik selalu semangat dan memiliki sikap kerja keras terhadap pekerjaan yang dijalankannya. Sikap tidak mudah menyerah adalah hal yang penting. Dengan disiplin, pekerjaan yang dijalankan dapat di selesaikan dengan baik.

6. Penerapan future orientation yaitu: Bale Hidroponik memiliki visi kedepan menjadi perusahaan pertanian yang dapat memenuhi semua kebutuhan konsumennya. Pemilik ingin usahanya berkembang dengan sistem autopilot dengan dikolola oleh sistem yang teratur.

7. Penerapan skill of organizing yaitu: pemilik usaha Bale Hidroponik memiliki pegawai tetap dan karyawan part time yang dilatih untuk mampu menjalankan tugas sesuai keterampilan. Pemilik selalu berusaha dalam pengelolaaan sumber 
daya yang kreatif, inovatif dan fleksibel guna untuk memenuhi kegiatan pemasaran serta memperoleh manfaat secara finansial.

8. Penerapan value of achievement over money yaitu: uang bukanlah hal yang diutamakan dalam bisnis ini. Namun, dari konsistensi mementingkan kepuasan konsumen dengan produknya yang membuat bisnis Bale Hidroponik ini berkembang.

9. Pemanfaatan bisnis online untuk mendukung sumber daya pemasaran dengan secara baik dan benar mampu mengantarkan usaha ini bersaing dari sisi harga, produk, marketing, jaringan, dan pelayanan.

\section{Daftar Pustaka}

Bambang, S., dan Ayu, N, H. 2015. Peran Sosial Media Untuk Manajemen Hubungan Dengan Pelanggan Pada Layanan E-Commerce. Value Added, Vol. 7, No. 2: 35.

Didin, H., dan Hendri, T. 2002. Manajemen Syari'ah dalam Praktek. Jakarta: Gema Insani Press.

Herman, H. 2018. Strategi Meningkatkan Keunggulan Bersaing Pt Putra Usaha Mandiri Kota Batam. Jurnal Akuntansi Barelang, Vol. 3, No. 1: 59.

Juditha, C. 2017. Memahami Struktur Jaringan Media Sosial sebagai Cara Strategis Periklanan di Era Ekonomi Digital. Jurnal Pekommas, Vol. 2, No. 1: 99-114.

Lubis, A. F., Anggraini, A. M. T., Toha, K., Kagramanto, L. B., Hawin, M., Sirait, N. N., Prananingtyas, P., Sukarmi, M. S., dan Silalahi, U. 2017. Hukum Persaingan Usaha, Edisi Kedua. Jakarta: Komisi Pengawas Persaingan Usaha.

Miles, M. B. 1992. Analisis Data Kualitatif. Jakarta: Universitas Indonesia Press.

Moleong. 2011. Metodologi Penelitian Kualitatif. Bandung: PT. Remaja Rosdakarya.

Notoatmodjo, S. 2005. Metodologi Penelitian Kesehatan. Jakarta: Rineka Cipta.

Nugroho, I. R. L. 2015. Identifikasi Karakteristik Wirausaha Dalam Menghadapi Persaingan (Studi Kasus Rendi Maulana, Owner Koren Denim Bandung 2014). E-Proceeding of Management Vol. 2, No. 2: 2-7.

Ramdani, A. Y. 2016. Identifikasi Karakteristik Wirausahawan Dalam Menghadapi Persaingan Bisnis (Studi Kasus Ir. Kunto Herwibowo Owner CV. Spirit Wira Utama). EProceeding of Management Vol. 3, No. 3: 3042.

Romdonny, J., Lucky, M., dan Rosmadi, N. 2018. Peran Media Sosial Dalam Mendukung Pemasaran Produk Organisasi Bisnis. Ikraith Ekonomika, Vol. 1, No. 2: 25-30.

Situmorang, S. H., Mulyono, H., dan Berampu, L. T. 2018. Peran dan Manfaat Sosial Media Marketing bagi Usaha Kecil. AJEFB - Asian Journal of Entrepreneurship and Family Business, Vol. 1, No. 2: 77-84.

Sulianta, F. 2012. Smart Online Marketing. Yogyakarta: Andi.

Suyanto, M. 2003. E - Commerce Perusahaan Top Dunia. Yogyakarta: Andi.

Syukron, M. 2016. Intelijensi Pemasaran Dalam Upaya Mempertahankan Keunggulan Kompetitif. Iqtishoduna, Vol. 9, No. 2: 144. 
Tritama, H. B., Tarigan, R. E. 2014. Pengaruh Media Sosial Terhadap Brand Awareness Produk Perusahaan. Tanggerang: Universitas Pelita Harapan.

Widyaningrum, P. W. 2016. Peran Media Sosial sebagai Strategi Pemasaran pada Sewa Kostum Meiyu Aiko Malang. Jurnal Al Tijarah, Vol. 2, No. 2: 33. 